\title{
Land Use Practices, Woody Plant Species Diversity and Associated Impacts in Maze National Park, Gamo Gofa Zone, Southwest Ethiopia
}

\author{
Wegene Getachew Andabo*, Feleke Woldeyes Gamo \\ Department of Biology, Arba Minch University, Arba Minch, Ethiopia \\ Email address: \\ wegishscho@gmail.com (W. G. Andabo), felekewoldeyes@yahoo.com (F. W. Gamo)
}

To cite this article:

Wegene Getachew Andabo, Feleke Woldeyes Gamo. Land Use Practices, Woody Plant Species Diversity and Associated Impacts in Maze National Park, Gamo Gofa Zone, Southwest Ethiopia. Plant. Vol. 3, No. 6, 2015, pp. 64-74. doi: 10.11648/j.plant.20150306.12

\begin{abstract}
The most recent attentions in biodiversity conservation efforts have been founded in the identification of land use practices and woody plant species in protected areas. Among such protected areas is Maze National Park located in Gamo Gofa Zone, South West Ethiopia. The Park was selected for this study with the objective of investigating land use practices, woody plant species diversity and the associated impacts for its management and sustainability. To achieve the intended objective, community resources were mapped, the different land use categories, drivers of land use change and impacts caused due to land use practices were identified. Vegetation data was collected from seventy 0.04 ha $(20 \mathrm{~m} \times 20 \mathrm{~m}$ each $)$ plots in seven transects. Cover abundance values were estimated using the modified Braun Blanquet scale of 1 to 8 . A total of 4 land use practices and 80 woody plant species belonging to 31 families and 58 genera were encountered being Fabaceae is the most dominant family. Six plant communities were identified by hierarchical cluster analysis using PC-ORD version 5. The data obtained were analyzed using appropriate indices, statistical tools and software. Despite the contributions of the park to the surrounding community and ecotourism, human and livestock population pressures were the major threats which will jeopardize the park's sustainability. The findings of this study pointed that the park is under serious risk of its biological diversity in general and that of woody plant species in particular due to consequent habitat deterioration, alteration and degradation. It is, therefore, recommended that timely measures should be taken by all stakeholders to sustain and realize the park's aesthetic, economic and ecotourism potentials.
\end{abstract}

Keywords: Land Cover, Land Use, Land Use Practices, Maze, Maze National Park, Sustainability

\section{Introduction}

Land is a basic natural resource used for a variety of purposes from survival to satisfaction of a wide range of human needs. Thus it can be deduced that land use refers to a series of activities done to generate one or more products or services humans do require from land (Karis and Jettou, 2013). For example, humans are the major force of change around the globe, transforming land to provide food, shelter, and products for use (ESA, 2000). Land use practices have become integral components of strategies in monitoring land cover changes (Mark and Kudakwashe, 2010). Land cover is the attribute of the earth's land surface and immediate subsurface, including biota, soil, topography, surface and groundwater, and human structures (Lambin et al., 2003). Land use - land cover pattern of a region determines changes in the environment and is determined by the land use practices in the natural and socioeconomic environment by man in time and space (Zubair, 2006). Land use change practices are a locally pervasive and globally significant ecological trend (Agarwal et al., 2002). Land covers are safety net for the rural poor during periods of economic and political transformation (Pattanayak and Sills, 2001); however population growth and immense agriculture have been the most massive pressures on land being causes for various land use practices that result in changes in the land cover (Mark and Kudakwashe, 2010). As various reports indicate (Kigomo, 2003, Lambin et al., 2001, 2003 and MEA, 2005), man has caused significant land cover change in the last decade.

The earth is facing increasing challenges from unsustainable land use practices that lead in to increased risks of climate change and rising hunger, poverty and malnutrition, land 
degradation and loss of biodiversity (Oke and Jamala, 2013). In addition, land degradation due to unsustainable land use practices directly affects the type of plants grown in area (Wondie Mebrat, 2015) particular of woody plant species diversity (Oke and Jamala, 2013). Sustainable land use and its productivity are functions of collaborative planning and implementation ( Abiyu Abrham and Gratzer, 2009).

Ostle et al. (2009) state that most of the practices in land use has direct effect on woody plant species of a region. Accordingly, changes in human activities often produce changes in spatial landscape heterogeneity through habitat fragmentation, monoculture, growth of some plant species beyond their ecological boundaries and suppression of native species by new plant species. Land use practices such as increased grazing pressure and decreased fire frequency have been associated with shifts from grass to woody plant domination (Van Auken, 2000). In the recent past, land use related research has evolved out of efforts to identify ecologically damaging land use practices (Olson et al., 2004 and Singh and Khanduri, 2011).

Global estimation on terrestrial land use practices has revealed $83 \%$ of the global terrestrial land surface has been affected and $60 \%$ of the ecosystems services in the past 50 years alone has been degraded by the human footprint. Accordingly, land use and the consequent change on land cover has become the most important driver of loss of biodiversity and other forms of land degradation (SD21, 2012). Globally, area coverage of protected areas has increased by 38\% in nine years period from 1992 - 2010. Despite the impressive increase in protected area, there is still a mismatch: because biodiversity naturally develops over a long time; and the establishment of a protected area and loss of biodiversity are a short time processes (SD21, 2012).

Parks are protected areas of diversified biodiversity; and Maze National Park is one of Ethiopian parks in which various land use practices were observed. Despite the studies conducted in other parks of the country, little is known about the land use practices, vegetation cover and impacts of land use practices in and around MNP. In light of the future sustainability of the park, it is, therefore, crucial to have a clear insight on land use - land cover change practices occurring in the park before a serious alteration occurs to the park ecosystem. The present study, therefore, is designed to investigate land use practices occurring in the park, woody plant composition of the park and the impacts of the practices thereby to generate data that would be used in the future management of the park.

\section{Materials and Methods}

\subsection{Description of the Study Area}

\subsubsection{Location and Natural Attractions of Maze National Park}

The study was conducted in Maze National Park (MNP) which is located at $6025^{\prime} \mathrm{N} 37014^{\prime} \mathrm{E}$ in Gamo Gofa Zone in South West Ethiopia. The name of the park "Maze" is derived after the largest river that crosses the park. Other rivers, which are tributaries to river Maze, in decreasing order of their size are Lemase, Domba and Zage rivers. The absence of study that focuses on land use practices and impacts on the vegetation of the area was the reason for the selection of the study site.

The park, which was established in 2005 was a controlled hunting area for many years starting from the Derg regime to its establishment; and it has been called "Shambara Bazuwa" where Shambara stands for Very Wide Area and Bazuwa stands for Wilderness or Desert by the local people. It lays within the boundaries of five weredas namely Qucha, Daramalo, Zala, Kamba and Denba Gofa (Figure 1). The Maze controlled hunting area was developed into national park for its endemic mammal Swayne Hartebeest (Alcelaphus buselaphus) of Ethiopia where the population of the Swayne Hartebeest (Alcelaphus buselaphus) is the third around the world (WMT, 2002). The park is located about 460, 235 and $22 \mathrm{kms}$ South West of Addis Ababa, Hawassa and Selam Ber, capital of Qucha wereda, respectively. GPS data has shown that the park covers an area of $220 \mathrm{~km} 2$ with altitudes ranging from 900 to 1400 meters above sea level.

The landscape of the park area includes a vast plain, some sloppy areas, small hills, escarpments and chain of mountains at its boundaries. Maze National Park and its surroundings have unique natural, cultural and historical attractions wide range of wildlife and vegetation types. (WMT, 2002). Bilbo Hot Spring, which is situated at the southern part of the park, is a natural beauty where hot water gushes out of the ground forming a fountain; and used by local people and those who come from distant places as a source of cure. Wenja stone cave is a natural rock cave in western surrounding of the park. It is attractive to sight and can accommodate about 300 hundred people at once. According to elders, the site was used to punish criminals from the community who were proved to be guilty.

Local communities around Maze National Park belong to the Omotic family. The major Nationality groups that live close to the park are the Qucha, Gamo and Gofa. According to Central Statistical Agency's census (2007), the population size of Zala, Daramalo, Denba Gofa, Qucha and Kamba weredas around MNP was 74,369; 81,025; 81,165; 149,287 and 155,979 respectively and it is projected to be 85,346 ; 93,$173 ; 92,651 ; 171,498$ and 179,046 in 2012 in the corresponding order (CSA, 2012). The primary means of subsistence of the population around Maze National Park is cereal cultivation followed by livestock production. However, tuber crops like sweet potato, taro, cassava and legumes are cultivated as supplement to cereals. 


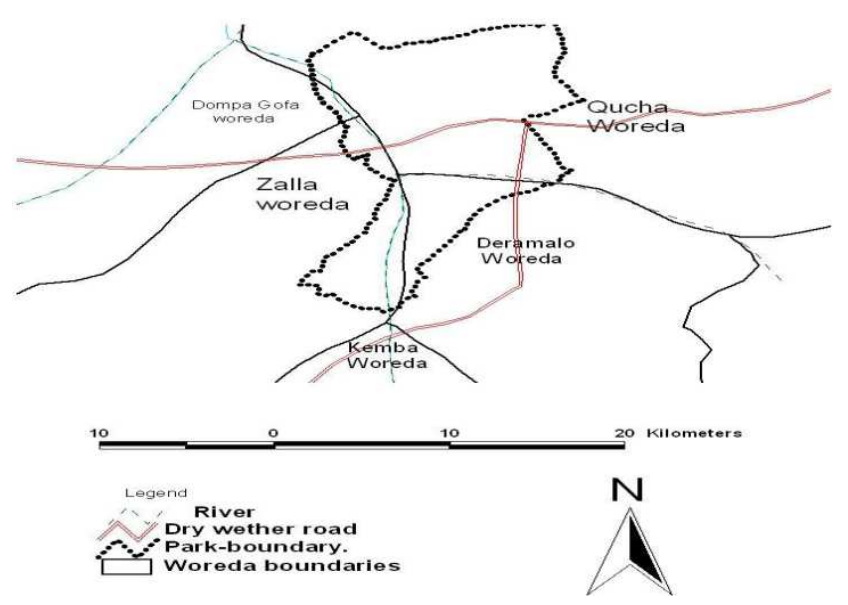

(Source: Southern nations nationalities and peoples regional state bureau of tourism and culture, 2010).

Figure 1. Map of Maze National Park and Surrounding Weredas.

\subsubsection{Climate of Maze National Park}

Meteorological data obtained from Morka station, which is located $2.5 \mathrm{kms}$ from the park, shows the highest average annual temperature recorded is $25.4^{\circ} \mathrm{C}$ while the lowest being $24.5^{\circ} \mathrm{C}$. On the other hand, the average annual precipitation varied between $802.5 \mathrm{~mm}$ and $1494.7 \mathrm{~mm}$ during the years 2001-2010.
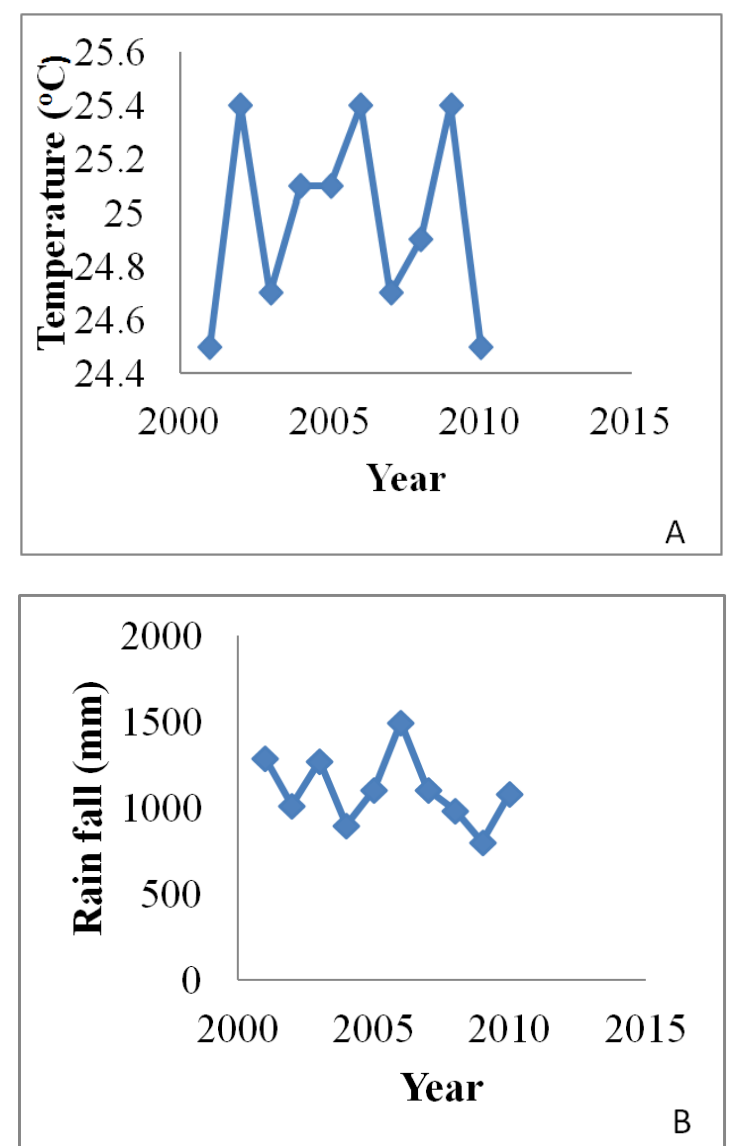

Figure 2. Annual average temperature $(A)$ and annual average rainfall $(B)$ (2001-2010) of Maze National Park. (Source: - Unpublished document of National Meteorological Agency, Hawassa Branch Office).

\subsection{Data on Trend of Land Use Practices}

Data on the trends of land use practices was gathered from direct observation, interviews and group discussions. The resources of the park and land use categories were mapped by the local communities around the park. Cover abundance values of the park were estimated using the modified Braun Blanquet scale of 1 to 8 as presented in Table 1 (Van der Maarl, 1979).

Table 1. Scale for estimation of cover-abundance value.

\begin{tabular}{ll}
\hline Abundance and percentage cover & Scale \\
\hline 1-5 individuals, cover $<5 \%$ & 1 \\
6-50 individuals, cover $<5 \%$ & 2 \\
More than 50 individuals, cover $<5 \%$ & 3 \\
Any number of individuals, cover 5-15\% & 4 \\
Any number of individuals, 16-25\% & 5 \\
Any number of individuals, 26-50\% & 6 \\
Any number of individuals, cover 51-75\% & 7 \\
Any number of individuals, cover $76-100 \%$ & 8 \\
\hline
\end{tabular}

\subsection{Data analysis}

Plant diversity was analysed using Shannon-Weiner index $\left(\mathrm{H}^{\prime}\right)$ which takes into account abundance and richness.

It was calculated using the Shannon-Weiner index $\left(\mathrm{H}^{\prime}\right)$ (Heuserr, 1998):

$$
\mathrm{H}^{\prime}=-\sum_{i=1}^{s} p i \ln p i
$$

Where, $\mathrm{H}^{\prime}=$ Shannon-Wiener diversity index, $\mathrm{P}_{\mathrm{i}}=$ the proportion of individuals or the abundance of $\mathrm{i}^{\text {th }}$ species, $\ln \mathrm{P}_{\mathrm{i}}$ $=\log _{\mathrm{e}} \mathrm{P}_{\mathrm{i}}$ and $\mathrm{S}=$ the number of species.

In addition, Simpson index (D) and Evenness index (E) that are considered as a measure of species dominances and a measure for evenness of spread respectively were calculated. While Simpson index was determined as (Hill, 1973):

$$
\mathrm{D}=\Sigma \mathrm{P}_{\mathrm{i}}^{2}
$$

Where, $\mathrm{P}_{\mathrm{i}}=$ the proportion of individual of each species.

Evenness index (E) was calculated using Pielou (1969) equation:

$$
\mathrm{E}=\frac{H^{\prime}}{\ln (S)}=\frac{H^{\prime}}{H \max }
$$

Where, $H^{\prime}=$ Shannon-Wiener Diversity Index, $H^{\prime} \max =\operatorname{lnS}$ $=$ the natural $\operatorname{logarithm}$ of the total number of species and $\mathrm{S}=$ total number of species in the sample.

Floristic similarities among different transects and plant communities were calculated by employing Sorensen's similarity coefficient (Kent and Coker, 1992) by using the equation:

$$
\mathrm{SC}=2 \mathrm{a} /(2 \mathrm{a}+\mathrm{b}+\mathrm{c})
$$

Where $\mathrm{a}=$ number of species common to both categories, $\mathrm{b}=$ number of species present in the first category and absent 
in the second and c = number of species present in the second category and absent in the first.

Plant communities were identified by hierarchical cluster analysis using PC-ORD version 5 (McCune and Mefford, 1999; McCune and Grace, 2002). The analysis was based on the presence/absence data of a species in a given releve. The Relative Euclidean Distance (RED) measures using Ward's method was used (van Tongeren, 1995; McCune and Grace, 2002).

\section{Result and Discussions}

\subsection{Resource Mapping by Local Communities Around Maze National Park}

Resources located in and the surroundings of MNP were mapped by local communities living around the park as shown in table 2 .

Table 2. Resource type, use and location in and around Maze National Park.

\begin{tabular}{|c|c|c|}
\hline Resource type & Use of the resource & $\begin{array}{l}\text { Location of the } \\
\text { resource }\end{array}$ \\
\hline $\begin{array}{l}\text { Zaro ne Shaafa/Streams } \\
\text { and Rivers }\end{array}$ & $\begin{array}{l}\text { Household and } \\
\text { livestock consumption }\end{array}$ & $\begin{array}{l}\text { In different margins } \\
\text { of the park }\end{array}$ \\
\hline $\begin{array}{l}\text { Kexo mittaa, Etiyo } \\
\text { mittaa/Timber, } \\
\text { Firewood }\end{array}$ & $\begin{array}{l}\text { Fuel, local } \\
\text { construction income } \\
\text { generation }\end{array}$ & All over the park \\
\hline Essaa/Honey & $\begin{array}{l}\text { Household use and } \\
\text { income generation }\end{array}$ & $\begin{array}{l}\text { Vegetation on sides } \\
\text { of rivers }\end{array}$ \\
\hline Maataa/Grass & $\begin{array}{l}\text { Feeding cattle, } \\
\text { thatching roof, local } \\
\text { mattress, making } \\
\text { income generation }\end{array}$ & $\begin{array}{l}\text { All over the park } \\
\text { except parts with } \\
\text { dense vegetation } \\
\text { cover }\end{array}$ \\
\hline $\begin{array}{l}\text { Shaafa Dona } \\
\text { Wora/Riverine forests }\end{array}$ & $\begin{array}{l}\text { Local construction, } \\
\text { income generation }\end{array}$ & Sides of rivers \\
\hline Mole/Fish & $\begin{array}{l}\text { Household } \\
\text { consumption }\end{array}$ & Rivers in the park \\
\hline Xabala/Hot spring & Therapy, purification & $\begin{array}{l}\text { Southern periphery } \\
\text { of the park }\end{array}$ \\
\hline Wora Do7a/Wildlife & Tourist attraction & $\begin{array}{l}\text { Mainly at central } \\
\text { part of the park }\end{array}$ \\
\hline
\end{tabular}

The community members clearly identify location of each resource and extract the resource as per their requirements which matched to Kelli and Mooney (2005) who reported that community resource mapping is important to classify available resources and use them in sustainable manner. Uses of resources from the park range from household consumption (e.g. drinking water, energy source, construction, cattle feed) through income generation to the household to maintenance of health of the local population. This, therefore, shows that community members around the park are knowledgeable about resources within the park and their livelihoods are strongly attached to the protected area.

The heavy reliance of local communities on Maze National Park is similar to the subsistence of over $70 \%$ of the world's poor who depend upon natural resources around their localities (Lipper and Cavatassi, 2003, Sunderlin et al., 2008 and IUCN, 2008).

\subsection{Land Use Categories and Drivers of Land Use Practices in Maze National Park}

Assessment on land use types revealed that there exist 4 land-use types (Wora Biittaa, Goshsha Biittaa, Mehiya Hemiyosa and Maze Shambara).

These land use types have ecological as well as subsistence functions; and the area under each land use type is changing from time to time with agricultural land and pastureland kept expanding progressively. In this regard, previous works indicated that agricultural expansion has changed natural vegetation to agroecosystems in many parts of the world (Lyaruu, 2002 and Tiffen, 2003). These changes are fuelled by a growing demand for agricultural products not only by the rural poor but also by the large-scale investors in commercial farming sector ().

Different drivers are responsible for the observed land-use change in the park area and disturbance of the park ecosystem. Human and livestock populations in the park's surrounding is continually increasing (CSA, 2007), and, therefore, population expansion is the main driver of land-use change as it caused increased demand for farmland, grazing land and timber and non-timber products. The conservation purpose without any economic benefit gained so far from the park management led to lack of sense of ownership of the park by local communities. This has been putting negative influence over the sustainability the park's resources. Therefore, to develop the sense of ownership, it has to be done in the awareness and commencement of local communities in the present and future socioeconomic and ecotourism potential of the park. For example, if properly managed, fishing and honey extraction will benefit local communities with house hold consumption and income generation.

Table 3. Land use types, pattern of land use and proportion of respondents categorizing the land use in Maze National Park.

\begin{tabular}{|c|c|c|c|c|c|}
\hline S.No. & Land use type & Description of land use type & $\begin{array}{l}\text { Pattern of land } \\
\text { use category }\end{array}$ & Indicators & $\begin{array}{l}\text { Proportion of respondents } \\
\text { categorized the land use }\end{array}$ \\
\hline 1 & Wora Biittaa & $\begin{array}{l}\text { Forest land: Riverine forests at Maze and } \\
\text { Lemase Rivers with closed canopies and } \\
\text { treesup to } 50 \text { meters }\end{array}$ & $\begin{array}{l}\text { Mostly at } \\
\text { aboriginal stand } \\
\text { of conservation }\end{array}$ & $\begin{array}{l}\text { High species diversity, } \\
\text { no tree cutting, closed } \\
\text { canopy }\end{array}$ & $62 \%$ \\
\hline 2 & Goshsha Biittaa & $\begin{array}{l}\text { Agricultural land: Cropping fields for } \\
\text { cultivation of cereals. }\end{array}$ & Expanding & $\begin{array}{l}\text { Diminishing of } \\
\text { parkland }\end{array}$ & $80 \%$ \\
\hline 3 & Mehiya Hemiyosa & $\begin{array}{l}\text { Pastureland: Cattle grazing fields. Includes } \\
\text { woodland, grassland and bushland }\end{array}$ & Expanding & Intrusion into the park & $91 \%$ \\
\hline 4 & $\begin{array}{l}\text { Maze Shambara } \\
\text { (Molsha Denba) }\end{array}$ & $\begin{array}{l}\text { Rangeland: Vast plain landscapes that } \\
\text { cover most of the park. Mainly savanna } \\
\text { grassland with semi-arid climates }\end{array}$ & $\begin{array}{l}\text { Almost at natural } \\
\text { state }\end{array}$ & Not highly disturbed & $73 \%$ \\
\hline
\end{tabular}


Changes in land use in MNP may also be attributed to changes in local life style since changing pattern of land-use and land-cover reflect changing economic and social conditions (Perz, 2002). As noted by Abebe Tadege (2007), climate variability of a region causes recurrent droughts that result in land-use change this appears to be true for Maze National Park. The areas around the park are experiencing high temperature and extended dry period. This obviously tempted people to encroach into the greener and presumably land of the park leading to new land-use systems.

Analysis of the different drivers that are identified to be the causes of land-use changes in the area are given in Table 4.

Table 4. Drivers of land use practices and their impacts in Maze National Park.

\begin{tabular}{|c|c|c|}
\hline S.No. & Driver & Impact \\
\hline 1 & $\begin{array}{l}\text { Demand for park area for } \\
\text { agriculture }\end{array}$ & Shrinking in land-cover \\
\hline 2 & $\begin{array}{l}\text { Demand for timber } \\
\text { products for construction } \\
\text { and household energy }\end{array}$ & $\begin{array}{l}\text { Deterioration of land-cover, rarity } \\
\text { of plant species }\end{array}$ \\
\hline 3 & $\begin{array}{l}\text { Demand for non-forest } \\
\text { product (honey) }\end{array}$ & Exposure of wildlife to danger \\
\hline 4 & Human population increase & Decrease in park area \\
\hline 5 & $\begin{array}{l}\text { Livestock population } \\
\text { increase }\end{array}$ & $\begin{array}{l}\text { Deterioration of wildlife } \\
\text { population due to competition for } \\
\text { grass and diseases }\end{array}$ \\
\hline 6 & Poverty & $\begin{array}{l}\text { Land fragmentation, land } \\
\text { degradation and land-cover } \\
\text { change }\end{array}$ \\
\hline 7 & Lack of sense of ownership & Depletion of resources in the park \\
\hline
\end{tabular}

\subsection{Disturbance Classes: Causative Agents of Land Use Change in Maze}

National Park

Maze National Park is surrounded by with increasing number of inhabitants and who progressively kept encroaching into the park and who also have interest in exploiting resources of the park for subsistence and income source. Therefore, the park is subject to continuous disturbance; and the present study showed that there exist eight disturbance classes (Table 5).

Table 5. Disturbance classes, disturbance pressure and consequences

\begin{tabular}{|c|c|c|}
\hline $\begin{array}{l}\text { Disturbance } \\
\text { classes }\end{array}$ & Disturbance pressure & Consequences \\
\hline Tree cutting & $\begin{array}{l}\text { Increased demand for } \\
\text { timber products }\end{array}$ & $\begin{array}{l}\text { Decline in Species } \\
\text { composition and diversity, } \\
\text { invasion by alien species } \\
\text { and ecosystem shift }\end{array}$ \\
\hline $\begin{array}{l}\text { Grass } \\
\text { trenching and } \\
\text { thatching }\end{array}$ & $\begin{array}{l}\text { Reduced availability of } \\
\text { grass for wildlife }\end{array}$ & $\begin{array}{l}\text { Competition between } \\
\text { wildlife and cattle, decline } \\
\text { in wildlife population }\end{array}$ \\
\hline $\begin{array}{l}\text { Grazing and } \\
\text { over grazing }\end{array}$ & $\begin{array}{l}\text { Decrease in regeneration } \\
\text { potential, vulnerability of } \\
\text { wildlife to danger, }\end{array}$ & $\begin{array}{l}\text { Nutrient scarcity and } \\
\text { ecosystem shift, wildlife } \\
\text { migration }\end{array}$ \\
\hline $\begin{array}{l}\text { Honey } \\
\text { extraction }\end{array}$ & $\begin{array}{l}\text { Uncontrolled movement } \\
\text { of people in the park }\end{array}$ & $\begin{array}{l}\text { Tree cutting to collect } \\
\text { forest honey, bushfire }\end{array}$ \\
\hline Agriculture & Use of land for growing & Habitat loss, impacts on \\
\hline
\end{tabular}

\begin{tabular}{lll}
\hline $\begin{array}{l}\text { Disturbance } \\
\text { classes }\end{array}$ & Disturbance pressure & Consequences \\
\hline Fishing & crops, bushfire & $\begin{array}{l}\text { ecosystem functions e.g., } \\
\text { water unsuitable for } \\
\text { drinking }\end{array}$ \\
in park region & $\begin{array}{l}\text { Decline in fish species, } \\
\text { disturbance of wildlife } \\
\text { Decline or removal of rare, } \\
\text { endangered and endemic } \\
\text { wildlife, decrease in eco- } \\
\text { tourism potential, conflict } \\
\text { over wildlife resource use }\end{array}$ \\
Road & Increased movement of & $\begin{array}{l}\text { Wildlife disturbance and } \\
\text { other resources depletion }\end{array}$ \\
\hline
\end{tabular}

\subsection{Vegetation Types of Maze National Park}

Although MNP area is dominated by grass land, field surveys revealed that there exist different vegetation types in the park. Accordingly, six vegetation types namely woodland, savanna, grassland with short to medium height trees, bushland, riverine forest and mixed type (woodland and grassland) are recognized in this study (Table 6).

Table 6. Vegetation types in Maze National Park.

\begin{tabular}{|c|c|c|}
\hline S.No. & Vegetation types & Description \\
\hline 1 & Woodland & $\begin{array}{l}\text { Dominated by tree species like Combretum } \\
\text { adenogonium, Maytenus arbutifolia and } \\
\text { Combretum molle that grow at lower } \\
\text { density forming open space for grass } \\
\text { species to thrive. This vegetation type } \\
\text { occupies plain and hilly part of the park. }\end{array}$ \\
\hline 2 & Savanna grassland & $\begin{array}{l}\text { Most dominant vegetation in the park. } \\
\text { Composed of grass species that grow on } \\
\text { average up to } 3 \text { meters }\end{array}$ \\
\hline 3 & $\begin{array}{l}\text { Grassland with } \\
\text { short to medium } \\
\text { height trees }\end{array}$ & $\begin{array}{l}\text { Characterized by tree species like Bridelia } \\
\text { scleroneura, Grewia bicolor and Ozoroa } \\
\text { insignis. This vegetation type dominate } \\
\text { sloppy regions of the park }\end{array}$ \\
\hline 4 & Bushland & $\begin{array}{l}\text { A dense cluster of tree species in this } \\
\text { category include Acacia drepanolobium, } \\
\text { Acacia nilotica, Xymenia americana and } \\
\text { Grewia ferruginea. Fragmented and in } \\
\text { some areas changing to bushy scrubland, } \\
\text { bushy tickets and bare land. }\end{array}$ \\
\hline 5 & Riverine forest & $\begin{array}{l}\text { The vegetation type consists of diverse tall } \\
\text { tree species like Combretum molle, } \\
\text { Lecaniodiscus fraxinifolius, Ficus exasperata } \\
\text { and Erithrina abyssinica and found at the } \\
\text { banks of Maze and Lemase Rivers }\end{array}$ \\
\hline 6 & $\begin{array}{l}\text { Mixed type } \\
\text { (woodland and } \\
\text { grassland) }\end{array}$ & $\begin{array}{l}\text { This vegetation type is highly exploited for } \\
\text { its location at the margins of the park. } \\
\text { Wooded grassland with characteristic tree } \\
\text { species like Acacia seyal, Maytenus } \\
\text { arbutifolia and Pilostigma thoninnigii. }\end{array}$ \\
\hline
\end{tabular}



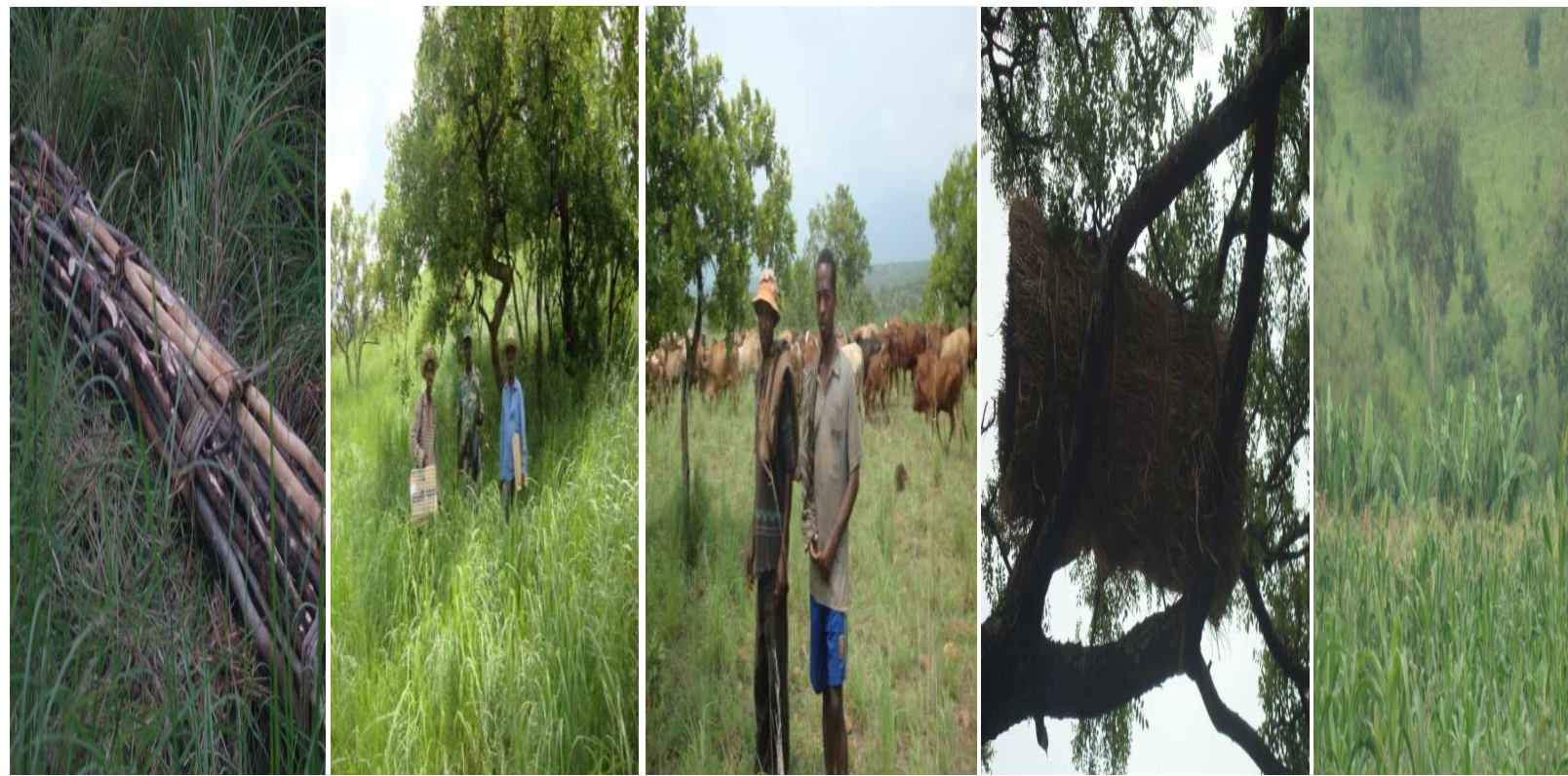

Figure 3. Disturbance classes: Tree cutting, grass trenching and thatching site, grazing, beehive, maize and banana cultivation in Maze National Park from photos directly taken from the park during the study time.

Six vegetation types namely woodland, savanna grassland, grassland with short to medium height trees, bush land, riverine forest and mixed type (woodland and grassland) are recognized in this study and this coincides largely with previously suggested vegetation classification of the park (WMT, 2002). The recognized six vegetation types differ from each other in such factors as characteristic species composition, tree/shrub density, physical feature of the land they occupy, habitat nature, and degree of disturbance by human. Of the recognized vegetation types, the most dominant vegetation types are grassland with small trees $(24 \%)$ and savanna grassland $(23 \%)$ and the least dense vegetation type is the mixed type (7\%) where tree species grow in significant abundance. The dominancy of grassland and savanna grassland vegetation types is attributed to the hot and dry climate of MNP that enjoys up to $1500 \mathrm{~mm}$ of precipitation in highly variable quantities during the rainy months. The local climatic situation, therefore, might have favored grass species which complete their lifecycle within a short period. In addition, the area is assumed to have experienced bushfire over long period of time, and this, in turn, must have contributed to dominance of grass species that can regenerate from their perennating organs situated underground and also few fire resistant woody species.

The 70 quadrats laid to sample vegetation data during the study fell in the different vegetation types in varying proportions with the maximum being in the grassland with short to medium height trees and the least being in mixed vegetation type (Figure 4).

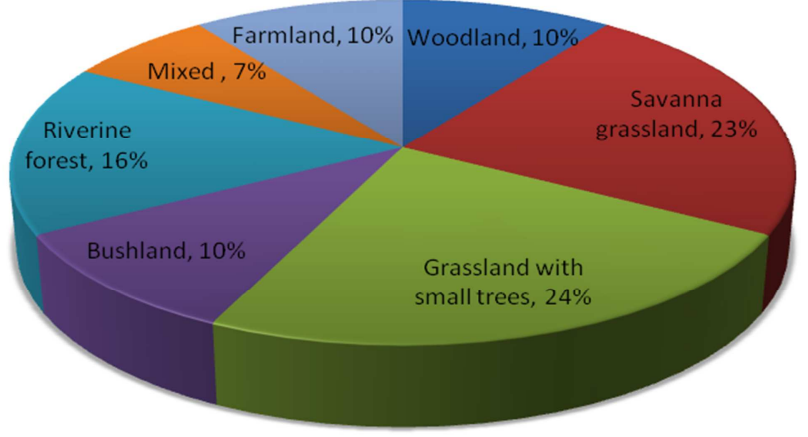

Figure 4. Proportion of quadrats fell on the different vegetation types of Maze National Park.

The two vegetation types namely savanna grassland and riverine forests are distinct for the largest area coverage and closed canopy in most areas of the lower altitudes of the park, respectively (Figure 5). Savanna grassland vegetation is a savanna rangeland with scattered medium sized trees mainly of Combretum and Acacia species. Riverine vegetation type is confined to rivers of the park and it is characterized by its tall trees.

\subsection{Species Composition and Diversity of Woody Plants in Maze National Park}

\subsubsection{Species Composition}

A total of 80 woody plant species that are distributed in 58 genera and 31 families were recorded from 70 quadrats laid in the 7 transects. Each plant family contained species that range in number from 1 to 17 (Table 7) while the most represented families are Fabaceae, Annacardiaceae, Moraceae, Euphorbiaceae and Combretaceae, respectively. 

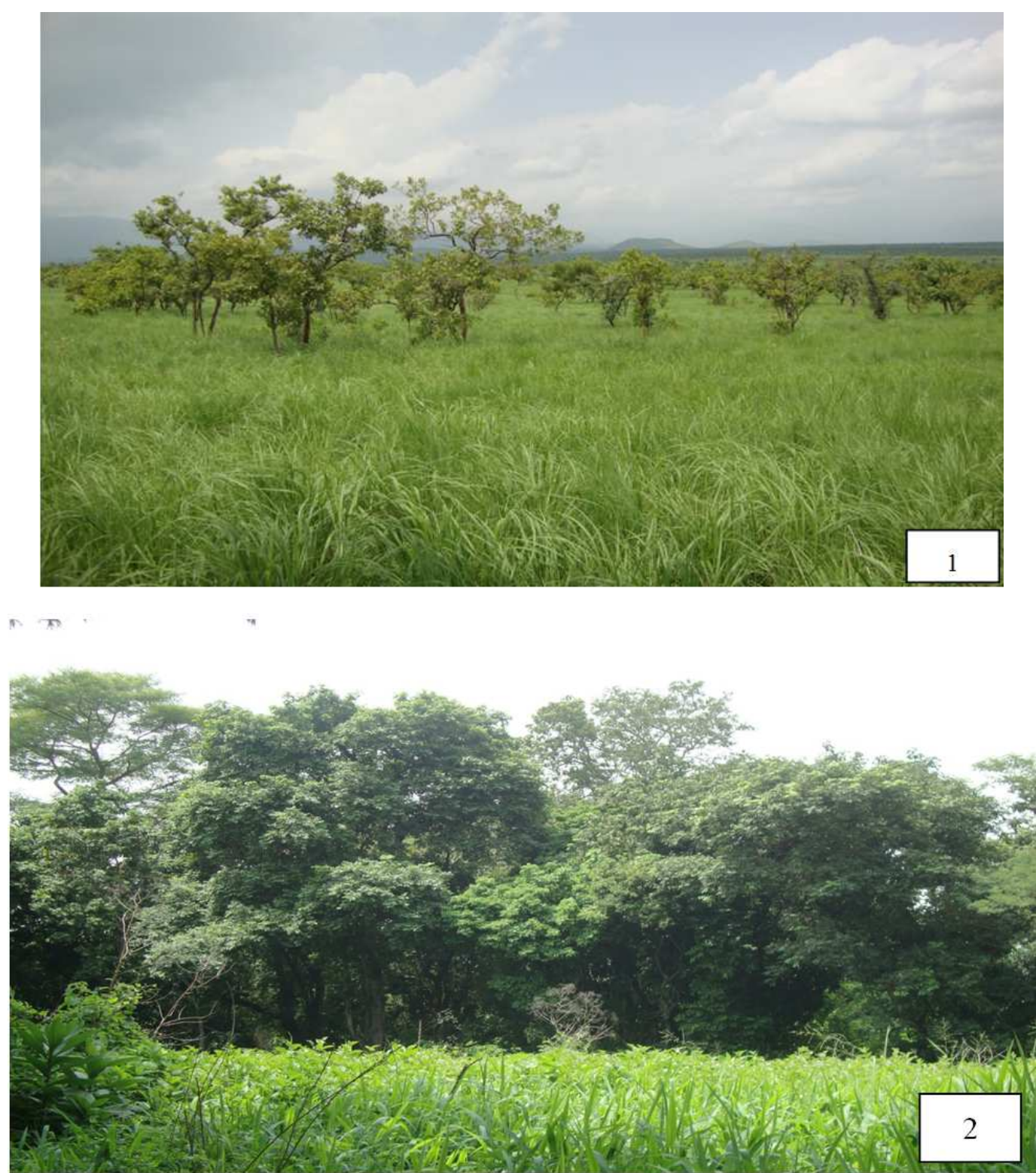

Figure 5. Savanna grassland (1) and maze river riverine forest (2) vegetation types in plains of Maze National Park.

Table 7. Woody plant composition of Maze National Park.

\begin{tabular}{llll}
\hline Family & $\begin{array}{l}\text { No. of } \\
\text { species }\end{array}$ & $\begin{array}{l}\text { No. of } \\
\text { genera }\end{array}$ & $\begin{array}{l}\text { \% contribution to the } \\
\text { total number of species }\end{array}$ \\
\hline Fabaceae & 17 & 11 & 21 \\
Annacardiaceae & 6 & 4 & 7.5 \\
Moraceae & 6 & 1 & 7.5 \\
Euphorbiaceae & 5 & 5 & 6.25 \\
Combretaceae & 5 & 2 & 6.25 \\
Sapindaceae & 4 & 4 & 5 \\
Celasteraceae & 4 & 2 & 5 \\
Tiliaceae & 3 & 1 & 3.75 \\
Meliaceae & 2 & 2 & 2.5 \\
Rubiaceae & 2 & 2 & 2.5 \\
Flacourtaceae & 2 & 2 & 2.5 \\
Boraginaceae & 2 & 2 & 2.5 \\
Caparidaceae & 2 & 2 & 2.5 \\
Rhamnaceae & 2 & 1 & 2.5 \\
Asteraceae & 2 & 1 & 2.5 \\
\hline
\end{tabular}

\begin{tabular}{llll}
\hline Family & $\begin{array}{l}\text { No. of } \\
\text { species }\end{array}$ & $\begin{array}{l}\text { No. of } \\
\text { genera }\end{array}$ & $\begin{array}{l}\text { \% contribution to the } \\
\text { total number of species }\end{array}$ \\
\hline Burseraceae & 1 & 1 & 1.25 \\
Olacaceae & 1 & 1 & 1.25 \\
Asparagaceae & 1 & 1 & 1.25 \\
Araliceae & 1 & 1 & 1.25 \\
Balanitaceae & 1 & 1 & 1.25 \\
Lamiaceae & 1 & 1 & 1.25 \\
Rutaceae & 1 & 1 & 1.25 \\
Dioscoreaceae & 1 & 1 & 1.25 \\
Caricaceae & 1 & 1 & 1.25 \\
Santalaceae & 1 & 1 & 1.25 \\
Annonaceae & 1 & 1 & 1.25 \\
Myrtaceae & 1 & 1 & 1.25 \\
Sterculiaceae & 1 & 1 & 1.25 \\
Bignoniaceae & 1 & 1 & 1.25 \\
Polygalaceae & 1 & 1 & 1.25 \\
Simarubaceae & 1 & 1 & 1.25 \\
\hline
\end{tabular}


The recorded 80 plant species have different densities with the most abundant species being Combretem adenogonium and Acacia drepanolobium achieving density values 142.86 and 38.57/ha., respectively (Table 8).

Table 8. Number and density of top ten species recorded from Maze National Park.

\begin{tabular}{llll}
\hline S.No. & Species name & $\begin{array}{l}\text { Total number } \\
\text { of individuals }\end{array}$ & $\begin{array}{l}\text { Density } \\
\text { (Individual } \\
\text { species/ha.) }\end{array}$ \\
\hline 1 & Combretum adenogonium & 400 & 142.86 \\
2 & Acacia drepanolobium & 108 & 38.57 \\
3 & Maytenus arbutifolia & 56 & 20.00 \\
4 & Harrisonia abyssinica & 51 & 18.21 \\
5 & Acacia seyal & 49 & 17.50 \\
6 & Grewia bicolor & 40 & 14.29 \\
7 & Ziziphus spina-cristi & 37 & 13.21 \\
8 & Bridelia scleroneura & 34 & 12.14 \\
9 & Combretum molle & 33 & 11.79 \\
10 & Pilostigma thonningii & 28 & 10.00 \\
\hline
\end{tabular}

\subsubsection{Diversity of Woody Plants}

Diversity analysis conducted on the woody vegetation of MNP as expressed by alpha and beta diversities revealed results varying from 2 to 7 and 11.4 to 39 , respectively while gamma diversity was found to be 80 (Table 9).
Table 9. Alpha, beta and gamma diversities of the park.

\begin{tabular}{llll}
\hline Transects & $\boldsymbol{\alpha}$-diversity & $\boldsymbol{\beta}$-diversity & $\boldsymbol{\gamma}$-diversity \\
\hline $\mathrm{T} 1$ & $\alpha 1=3$ & $\beta 1=26$ & \\
$\mathrm{~T} 2$ & $\alpha 2=3$ & $\beta 2=26$ & \\
$\mathrm{~T} 3$ & $\alpha 3=6$ & $\beta 3=12.3$ & \\
$\mathrm{~T} 4$ & $\alpha 4=7$ & $\beta 4=11.4$ & 80 \\
$\mathrm{~T} 5$ & $\alpha 5=2$ & $\beta 5=39$ & \\
$\mathrm{~T} 6$ & $\alpha 6=2$ & $\beta 6=39$ & \\
$\mathrm{~T} 7$ & $\alpha 7=2$ & $\beta 7=39$ & \\
\hline
\end{tabular}

\subsection{Woody Plant Communities in Maze National Park}

The cluster analysis which was conducted to determine plant community types revealed existence of six community types in the park (Figure 6).

Each community type is named after one, two or three dominant species that have had the highest cover estimates in it. The top five woody plant species with the highest mean cover abundance values from each community are presented in Table 10. The six community types recognized exhibit characteristic features in terms of species composition and altitudinal distribution as described below.

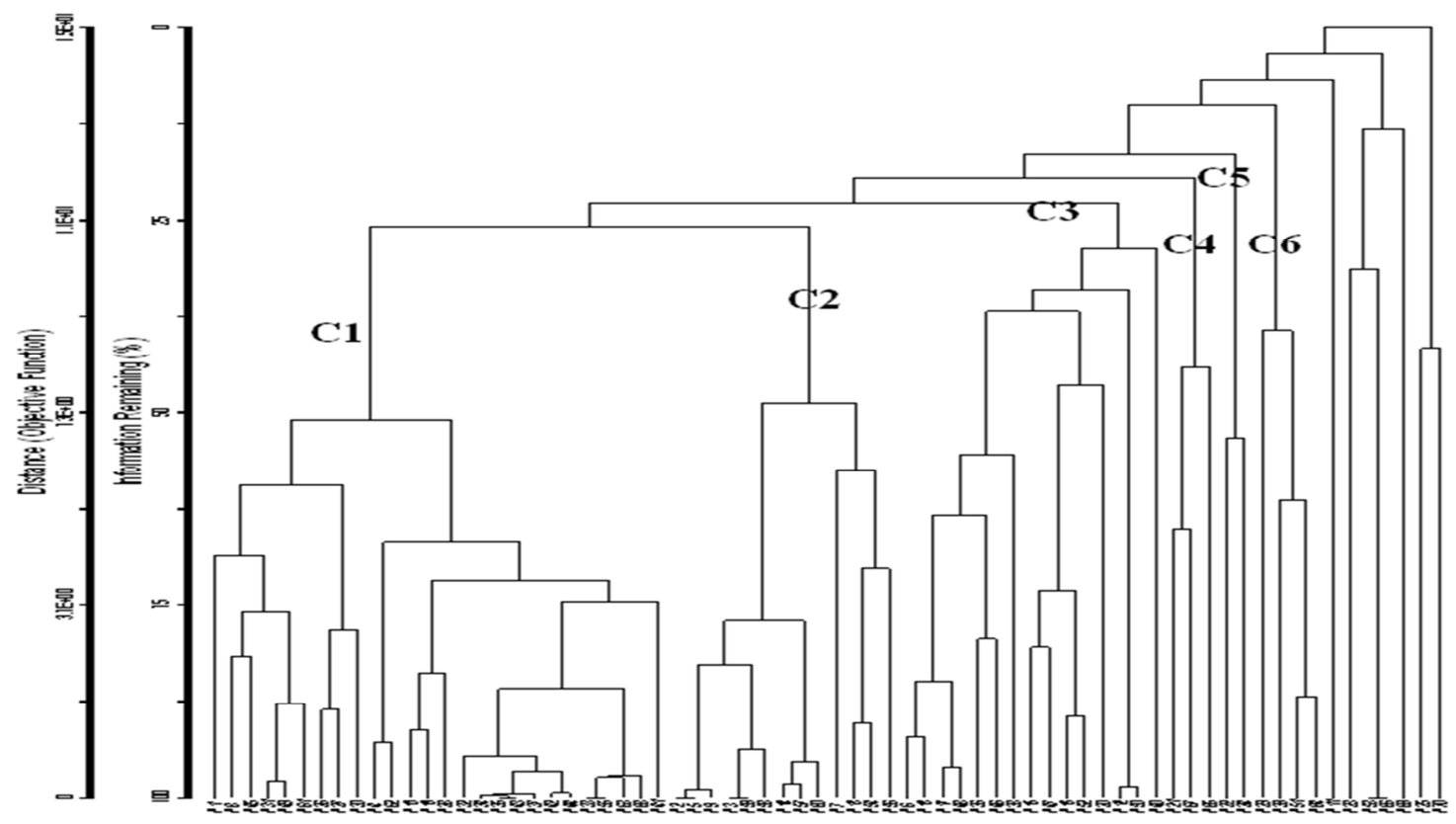

Figure 6. Woody plant communities of Maze National Park (Cluster numbers C1,C2,C3,C4,C5 and C6 represent each community)

Where, C1: Combretum adenogonium Community

Plots: 1,8,45,31,49,61,26,27,30,4,62,10,19,28,32,34,35,43,37,42,44,33,55,63,68,41

C2: Acacia drepanolobium-Combretum adenogonium Community

Plots: 2,5,9,3,59,58,14,57,60,7,13,54,56

C3: Acacia seyal-Balanites aegyptiaca-Combretum molle Community

Plots: $6,18,17,48,36,46,38,15,47,16,52,20,12,50,40$

C4: Terminalia brownit-Ficus exasperata-Acacia polyacantha Community

Plots: 21,67,65

C5: Trichilia emetica-Dicrostachys cineria Community

Plots: 22,24 and

C6: Combretum collinum-Acacia polyacantha-Combretum molle Community

Plots: 29,39,51,64 
Table 10. The top five plant species with the highest mean cover abundance values and altitudinal ranges in each of the identified plant communities. $(\bar{x}=$ mean, Cov. = cover, abund.$=$ abundance, $\bar{x}$ Cov.-abund.$=$ mean cover-abundance value and $m$ asl $=$ meters above sea level).

\begin{tabular}{|c|c|c|c|c|c|c|c|c|c|c|c|c|}
\hline \multirow{3}{*}{ S.No. } & \multicolumn{12}{|c|}{ Community types } \\
\hline & \multicolumn{2}{|c|}{$1(941 \mathrm{~m}$ to $1129 \mathrm{~m}$ asl $)$} & \multicolumn{2}{|c|}{$2(935 m-1102 m$ asl $)$} & \multicolumn{2}{|c|}{$3(931 \mathrm{~m}$ to $1118 \mathrm{~m}$ asl $)$} & \multicolumn{2}{|c|}{$4(932 \mathrm{~m}$ to $1006 \mathrm{~m}$ asl $)$} & \multicolumn{2}{|c|}{$5(927 \mathrm{~m}$ and $1022 \mathrm{~m}$ asl $)$} & \multicolumn{2}{|c|}{$6(1011 \mathrm{~m}$ to $1090 \mathrm{~m}$ asl $)$} \\
\hline & $\begin{array}{l}\text { Scientific } \\
\text { name }\end{array}$ & $\begin{array}{l}\bar{x} \text { Cov.- } \\
\text { abund. }\end{array}$ & $\begin{array}{l}\text { Scientific } \\
\text { name }\end{array}$ & $\begin{array}{l}\bar{x} \text { Cov.- } \\
\text { abund. }\end{array}$ & $\begin{array}{l}\text { Scientific } \\
\text { name }\end{array}$ & $\begin{array}{l}\text { xCov.- } \\
\text { abund. }\end{array}$ & $\begin{array}{l}\text { Scientific } \\
\text { name }\end{array}$ & $\begin{array}{l}\overline{\mathbf{x}} \text { Cov.- } \\
\text { abund. }\end{array}$ & Scientific name & $\begin{array}{l}\overline{\mathbf{x} C o v .-} \\
\text { abund. }\end{array}$ & $\begin{array}{l}\text { Scientific } \\
\text { name }\end{array}$ & $\begin{array}{l}\bar{x} \text { Cov.- } \\
\text { abund. }\end{array}$ \\
\hline 1 & $\begin{array}{l}\text { Combretum } \\
\text { adenogonium }\end{array}$ & 3.85 & $\begin{array}{l}\text { Acacia } \\
\text { drepanolobium }\end{array}$ & 2.5 & $\begin{array}{l}\text { Balanites } \\
\text { aegyptiaca }\end{array}$ & 2.33 & $\begin{array}{l}\text { Acacia } \\
\text { polyacantha }\end{array}$ & 3 & Trichilia emetica & 4.5 & $\begin{array}{l}\text { Combretum } \\
\text { collinum }\end{array}$ & 3.5 \\
\hline 2 & $\begin{array}{l}\text { Bridelia } \\
\text { scleroneura }\end{array}$ & 1.39 & $\begin{array}{l}\text { Combretum } \\
\text { adenogonium }\end{array}$ & 1.85 & Acacia seyal & 1.9 & $\begin{array}{l}\text { Terminalia } \\
\text { brownii }\end{array}$ & 2.33 & $\begin{array}{l}\text { Dichrostachys } \\
\text { cinerea }\end{array}$ & 3 & $\begin{array}{l}\text { Acacia } \\
\text { polyacantha }\end{array}$ & 1.25 \\
\hline 4 & $\begin{array}{l}\text { Combretum } \\
\text { molle }\end{array}$ & 0.85 & Grewia bicolor & r 0.62 & $\begin{array}{l}\text { Rhus } \\
\text { natelensis }\end{array}$ & 1.33 & Ficus sur & 1.7 & $\begin{array}{l}\text { Ehretia } \\
\text { abyssinica }\end{array}$ & 2 & $\begin{array}{l}\text { Terminalia } \\
\text { schimperiana }\end{array}$ & 1 \\
\hline 5 & $\begin{array}{l}\text { Lonchocarps } \\
\text { laxiflorus }\end{array}$ & 0.81 & $\begin{array}{l}\text { Harrisonia } \\
\text { abyssinica }\end{array}$ & 0.54 & $\begin{array}{l}\text { Ziziphus } \\
\text { spina-criti }\end{array}$ & 0.93 & $\begin{array}{l}\text { Sclerocharya } \\
\text { birrea }\end{array}$ & 1.33 & $\begin{array}{l}\text { Acalypha } \\
\text { villicaulis }\end{array}$ & 0.5 & $\begin{array}{l}\text { Albizia } \\
\text { grandibracteata }\end{array}$ & 0.5 \\
\hline
\end{tabular}

\subsection{Diversity of Woody Plant Communities}

The six woody plant communities of the park were composed of a total of 72 species from 63 quadrats. The communities varied in their species richness and other measures of diversity and evenness. Accordingly, while the species richness of the communities ranged from 10 to 37 , the Shannon-Weiner index of the wood species communities was found to range from 1.65 to 2.75 where as the Simpson index and the Evenness index ranged from 0.11 to 0.33 and 0.3 to 0.8 respectively (Table 11 ).

Table 11. Shannon diversity, Simpson and Evenness indices of woody plant communities.

\begin{tabular}{lllll}
\hline $\begin{array}{l}\text { Woody plant } \\
\text { community }\end{array}$ & $\begin{array}{l}\text { Species } \\
\text { richness }\end{array}$ & $\begin{array}{l}\text { Shannon } \\
\text { index, } \mathbf{H}^{\prime}\end{array}$ & $\begin{array}{l}\text { Simpson } \\
\text { index, }, \mathbf{D}\end{array}$ & $\begin{array}{l}\text { Evenness } \\
\text { index, } \mathbf{E}\end{array}$ \\
\hline $\mathrm{C} 1$ & 37 & 1.94 & 0.33 & 0.3 \\
$\mathrm{C} 2$ & 18 & 1.65 & 0.29 & 0.32 \\
$\mathrm{C} 3$ & 33 & 2.75 & 0.11 & 0.53 \\
$\mathrm{C} 4$ & 11 & 2.12 & 0.139 & 0.66 \\
$\mathrm{C} 5$ & 10 & 2.15 & 0.138 & 0.8 \\
$\mathrm{C} 6$ & 10 & 2.05 & 0.16 & 0.685 \\
\hline
\end{tabular}

\subsection{Floristic Similarity in Maze National Park}

\subsubsection{Floristic Similarity among Transects}

The different transects laid for the purpose of this study showed similarity in species composition to a varying degree with the highest similarities being observed between transects 2 and $6(67 \%)$ while the lowest between transects 1 and $3(20 \%)$ and transects 1 and $4(20 \%)$ (Table 12).

Table 12. Sorensen's similarity coefficient among the seven transects.

\begin{tabular}{llllllll}
\hline Transect & $\mathbf{1}$ & $\mathbf{2}$ & $\mathbf{3}$ & $\mathbf{4}$ & $\mathbf{5}$ & $\mathbf{6}$ & $\mathbf{7}$ \\
\hline 1 & 1 & & & & & & \\
2 & 0.5 & 1 & & & & & \\
3 & 0.2 & 0.4 & 1 & & & & \\
4 & 0.2 & 0.3 & 0.3 & 1 & & & \\
5 & 0.45 & 0.5 & 0.26 & 0.43 & 1 & & \\
6 & 0.44 & 0.67 & 0.33 & 0.3 & 0.44 & 1 & \\
7 & 0.38 & 0.51 & 0.33 & 0.29 & 0.33 & 0.5 & 1 \\
\hline
\end{tabular}

\subsubsection{Floristic Similarity among Communities}

Floristic similarity among communities was also assessed to determine the degree of similarity among plant communities. The study revealed that the six communities exhibit a varying degree of species similarity with the maximum being between community 1 and community 3 (0.42) and community 2 and community $3(0.42)$ while the other extreme being complete dissimilarity which is observed between community 5 and community $6(0)$ (Table 13).

Table 13. Sorensen's similarity coefficient among the six communities.

\begin{tabular}{lllllll}
\hline Community & $\mathbf{1}$ & $\mathbf{2}$ & $\mathbf{3}$ & $\mathbf{4}$ & $\mathbf{5}$ & $\mathbf{6}$ \\
\hline 1 & 1 & & & & & \\
2 & 0.36 & 1 & & & & \\
3 & 0.42 & 0.42 & 1 & & & \\
4 & 0.2 & 0.28 & 0.19 & 1 & & \\
5 & 0.09 & 0.07 & 0.05 & 0.1 & 1 & \\
6 & 0.2 & 0.13 & 0.15 & 0.1 & 0 & 1 \\
\hline
\end{tabular}

\subsection{The State of Invasive in Maze National Park}

As stated by the park warden, so far, there are no invasive and encroacher species. But, field observations made during the study, however, realized two invasive species, Partinum hysterophorus that grows along the course of River Domba in the eastern part of the park forming a dense cover; and Dichrostachys cineria which was found to grow along the main road through MNP to Sawla town. Otherwise, most of the park area is free of infestation by invasive species at present. The condition of encroachment of invasive species now in MNP has to be a big deal as encroachment of invasive alien species is a globally common phenomenon and often has detrimental effects on rural households and native plant species of developing countries (GIZ, 2014).

\section{Conclusions and Recommendations}

The present study has shown that Maze National Park has appreciably high floristic diversity in general and woody species in particular. The diversity is observed at different levels, i.e., at species level, generic level, family level, vegetation community level and even habitat level. Nevertheless the park is experiencing a continued change in land use system from time to time. The change in land use system is mainly triggered by human and livestock 
population pressure and the perceived high productivity of the park area and the consequent encroachment by people.

The ongoing land use change has causing negative impact which is manifested through vegetation cover dwindling, decrease in density of some woody species, decline in diversity of the parks vegetation in general and woody species in particular, habitat degradation and a consequent susceptibility to invasion by encroacher and alien species, decline in wildlife population and perhaps local extinction of some of the floral and faunal species. With the present mounting interest to utilize the park's resources and also improved availability of facilities like road and health services, it is likely that intrusion in to the park's ecosystem and disruption of its functioning will be aggravated. This will, therefore, put in danger the sustainability of the park. The overall effect of this will be diverse, including unwanted impacts on the livelihoods of local people who are highly dependent on resources drawn from the park and also degradation of the ecotourism potential of the protected area which can significantly contribute to both local and national economies. Therefore, timely appropriate interventions are extremely essential to curb the challenges the park is confronted with. Cognizant of this fact, the below listed recommendations are made so as to ensure the park's sustained existence.

- Awareness creation activities with respect to conservation of the park should be conducted and the local community members should be involved in conservation efforts as stakeholder.

- A system that promotes a wise utilization of resources within the park by community members should be established in consultation with the local people.

- Effort should be made to stop further encroachment into the park area in search of farm and pasture lands by involving all those concerned.

- Collecting and burning invasive species to prevent and control further invasion through local community participation.

- Strategies such as provision of alternative energy sources and construction materials should be designed so as to minimize the pressure being exerted on the park.

- Alternative income generation schemes must be thought of to avoid illegal tree cutting for sell, excessive movement in the park for purpose such as honey search, and also the possible future charcoal making.

- Specific water points for livestock should be established so as to avoid roaming of cattle in the park.

- Mechanism of resolving boundary disputes that may arise among local communities adjacent to the park need to be put in place.

- Attempt should be made to subdivide the park's area into different regions such as buffer, reserve and core zones.

- Further detail studies using aerial photographs, remote sensing and geographic information system should be conducted on land use and land cover change patterns, vegetation of the park and other resources.

\section{References}

[1] Abebe Tadege (2007). Climate change national adaptation program of action of Ethiopia. The federal democratic republic of Ethiopia ministry of water resources national meteorological agency, Addis Ababa, Ethiopia.

[2] Abiyu Abrham and Gratzer, G., (2009). Native woody plants for livelihood in North Western Ethiopia: drivers of diversity and management constraints. Conference on international research on food security, natural resource management and rural development, University of Hamburg.

[3] Agarwal, C., Green, G., Grove, J., Evans, T. and Schweik, C. (2002). A Review and Assessment of Land-Use Change Models: Dynamics of Space, Time, and Human Choice. General Technical Report 297, pp61. Newtown Square, Pennsylvania, U.S.

[4] CSA (2007). The 2007 Population and Housing Census of Ethiopia. Results for Southern

[5] Nations, Nationalities and Peoples' Region. Part I: Statistical Report on Population Size and Characteristics, Addis Ababa.

[6] CSA (2012). Statistical Projection on Population Size by Sex, Area and Density on July 2012 from 2007 population census. Section B, Addis Ababa.

[7] Ecological Society of America (ESA), (2000). Ecological principles for managing land use: Brochure on key ecological principles for land use and management deal with time, species, place, disturbance, and the landscape. The principles result in several guidelines that serve as practical rules of thumb for incorporating ecological principles into making decisions about the land.

[8] GIZ, (2014). Managing prosopis Juliflora for better (agro-) pastoral livelihoods in the Horn of Africa. Proceedings of the regional conference, Addis Ababa, Ethiopia.

[9] Heuserr, M. (1998). Putting diversity indices into practice. Some considerations for forest management in the Netherlands. Proceedings of the Conference on assessment of biodiversity for improved forest planning, October 7-11, Kluwer Academic Publishers, Monte Verita, Swizerland.

[10] Hill, M. (1973) "Diversity and evenness: a unifying notation and its consequences". Ecology, 54, 427-432.

[11] IUCN (2008). Causes of forest land use change. In: Encyclopedia of Earth. Cutler J. Cleveland eds.,Washington, D.C., USA.

[12] Karis, A. and Jettou, D., (2013). Land use and land management practices in environmental

[13] Perspective.

INTOSAI

WGEA, http://www.environmentalauditing.org. ISBN 978-9949-90619-2 (PDF).

[14] Kelli, C. and Mooney, M. (2005). Community Resource Mapping for improving Secondary Education and Transition for Youth with Disabilities. Institute on Community Integration Publications, University of Minnesota.

[15] Kent, M. and Coker, P. (1992). Vegetation Description and Analysis: A practical Approach. Belhaven Press, London, 263pp. 
[16] Kigomo, B. (2003). Forests and woodlands degradation in dry land Africa: a case for urgent global attention. Paper presented at XII World Forest Congress, Quebec City. Retrieved from www.fao.org/DOCREP/ARTICLE/WFC/XII/0169-B3. html on Dec 21, 2011 at 4:37 am (UK).

[17] Lambin, E., Turner, B., Geist, H., Agbola, S., Angelsen, A., Bruce, J., Coomes, O., et al. (2001). The causes of land-use and land-cover change: moving beyond the myths. Glob. Environ. Chan. 11: 261-269.

[18] Lambin, E., Geist, H., and Lepers, E. (2003). Dynamics of land-use and land-cover change in tropical regions. Annu. Rev. Environ. Resour. 28: 205-241.

[19] Lipper, L. and Cavatassi, R. (2003). Land use change, carbon sequestration and poverty alleviation. Agriculture and Economic Development Analysis Division (ESA) working paper No. 03-13, Rome, Italy.

[20] Lyaruu, H., (2002). Plant biodiversity component of the land use change, Impacts and dynamics project, Mt. Kilimanjaro, Tanzania. 43pp.

[21] Mark, M. and Kudawashe, M. (2010). Rate of land use/land cover changes in Shurugwi District, Zimbabwe: Drivers for Change. Jour.sus. dev.Afr. 12 (3).

[22] McCune B. and Mefford, M. (1999). PC-ORD. Multivariate Analysis of Ecological Data. Version 5.0 MjM software, Gleneden Beach, Oregon, USA.

[23] McCune B. And Grace, J. (2002). Analysis of Ecological Communities. Version 5.0 MjM Software design, USA, 304pp.

[24] MEA (2005). Ecosystem and Human Well-being: Synthesis. Island Press, Washington DC.

[25] Nzunda, N., Munishi, P., Soka, G. and Monjare, J., (2013). Influence of socio-economic factors on land use and vegetation cover changes in and around kagoma forest reserve in Tanzania.

[26] Oke, DO and Jamala, JY. (2013). Traditional agroforestry practices and woody species conservation in the derived savanna ecosystem od Adamawa state, Nigeria. Biodiv. J., 4(3), $427-434$.

[27] Olson, J., Misana, S., Campell, D., Mbonile, M. and Mugisha, S. (2004). Land use change leading to land degradation and changing biodiversity. Land use change impacts and dynamics project working paper 48. : International livestock research institute, Nairobi, Kenya.

[28] Ostle, N., Levy, P., Evans, C. and Smith, P. (2009). UK Land use and soil carbon sequestration. Land use policy 26S: S274S283.
[29] Pattanyak, S. and Sills, E. (2001). Do tropical forests provide natural insurance? The microeconomics of non-timber products collection in the Brazilian Amazon. Land Econ. 77(4): 595-612.

[30] Perz, S. (2002). The changing social contexts of deforestation in the Brazilian Amazon. Soc. Sci. Quart. 83 (1).

[31] Pielou, E. (1969). An Introduction to Mathematical Ecology. Wiley-Interscience, Toronto.

[32] Singh, P and Khanduri, K. (2011). Land use and land cover change detection through remote sensing and GIS technology: Case study of Pathankot and Dhar Kalan Tehsils, Punjab. Interna. Jour. geomatics and geosci. 1(4).

[33] SNNPRSBCT (2010). Maze National Park, Awassa.

[34] Sunderlin, W., Dewi, S., Puntodewo, A., Müller, D., Angelsen, A. and Epprecht, M. (2008). Why forests are important for global poverty alleviation: a spatial explanation. Ecol. and Soc. 13(2):24. [online] URL: http://www.ecologyandsociety.org/vol13/iss2/art24/

[35] Sustainable Development in the $21^{\text {st }}$ century (SD21), (2012). Sustainable land use for the $21^{\text {st }}$ century.

[36] Tiffen, M., (2003), Transition in Sub-Saharan Africa: Agriculture, Urbanization and Income growth. World develop., $31,1343-1366$.

[37] Van Auken, O. (2000). Shrub invasions of North American semiarid grasslands. Ann. Rev. Eco. and Syst. 31:197-215.

[38] Van der Maarel (1979). Transformation of Cover-Abundance Values in Phytosociology and Its Effects on Community Similarity. Vegetatio 39(2):97-114.

[39] Van Tongeren, O. (1995). Cluster analysis. In: Data Analysis in Community Ecology and Landscape Ecolgy (Jongman, R,H.G., ter Braak, J.C.F and van Tongeren, O.F.R., eds.). Cambridge University Press, Cambridge, 174-212pp.

[40] WMT (2002). Southern Nation Nationalities People's Region natural resources and agricultural office. A survey report of Maze wildlife reserve.

[41] Wondie Mebrat, (2015). Natural regeneration practice in degraded high lands of Ethiopia through area enclosure. Science publishing group: Int. j. env. Prot. and pol., 3 (5), 120-123. doi: 10:11648/j.ijepp.20150305.11.

[42] Zubair, O. (2006). A study on change detection and land ues/land cover of Ilorin and its environs in Kwara State. M. Sc. Thesis, University of Ibadan, Nigeria. 